\title{
Хімічне травлення сплаву БРБ2 в різних електролітах
}

\author{
Л.М. Єгорова ${ }^{1}$, В.В. Даценко ${ }^{2}$, В.І. Ларін ${ }^{3}$ \\ 1,2 Харківський національний автомобільно-дорожній університет (м. Харків, Україна) \\ ${ }^{3}$ НДІ хімії при ХНУ ім. В.Н. Каразіна, (м. Харків, Україна) \\ email: 1 lilyaegorova@ukr.net; ${ }^{2}$ dacenkovita14@gmail.com \\ ORCID: ${ }^{1}$ 0000-0003-3491-63-35; ${ }^{2}$ 0000-0001-8331-8863; 3 10000-0002-1136-9626
}

\begin{abstract}
Досліджено процес хімічної іонізації сплаву БрБ2 в розчинах різного складу на основі $\mathrm{FeCl}_{3}$. На підставі першопочаткових досліджень визначення швидкості іонізації сплаву Cu98Be в різних електролітах розчин $\mathrm{FeCl}_{3}$ був обраний основним компонентом розчину для травлення. Вибрана серія з п'яти складів розчинів для травлення, які забезпечують високу швидкість травлення та рівномірне розчинення компонентів берилієвої бронзи. По мірі розчинення компонентів сплаву БрБ2 змінюється склад травильного розчину і, відповідно, швидкість розчинення компонентів сплаву. У зв'язку з цим дуже важливою є перевірка стабільності процесу травлення берилієвої бронзи в часі. Для цього було досліджено зміну швидкості розчинення сплаву БрБ2 в часі. Згідно з експериментальними даними були обчислені кількісні показники травлення та запропоновано склад розчинів, що забезпечують високу швидкість. 3 метою визначення селективності хімічного розчинення БрБ2 був вивчений процес травлення в розчинах хлориду заліза протягом тривалого періоду часу. Як кількісні показники рівномірності травлення були визначені коефіцієнти селективності розчинення компонентів сплаву. Показано, що в кислому середовищі в присутності іонів-окислювачів $\mathrm{Fe}^{3+}$ та іонів хлору можливе рівномірне та високо ефективне хімічне розчинення берилієвої бронзи. Запропоновано оптимальні склади травильних розчинів, що забезпечують якісне травлення берилієвої бронзи за кількома критеріями - висока швидкість процесу, рівномірне розчинення компонентів сплаву, висока ємність обох компонентів берилієвої бронзи. Отримані результати мають велике значення при практичному використанні, оскільки дозволяють вибрати склад травильного розчину, що, в свою чергу, допомагає оптимізувати технологічний процес травлення.
\end{abstract}

Ключові слова: берилієва бронза, травлення, травильні розчини, селективність розчинення.

\section{Постановка проблеми та ії актуальність.}

Мінерально-сировинна база кольорової металургії України є недостатньою і тому певна кількість підприємств даної галузі працюють на привізній сировині або переплавляють брухт кольорових металів .Як відомо, істотним забруднювачем навколишнього середовища важкими металами є кольорова металургія.[1].У той же час джерелом поповнення ресурсів брухту кольорових металів частково може стати виробництво плат, де мідь та її сплави використовуються як провідниковий матеріал і стравлюються при обробці поверхні (нанесення малюнка, травлення). Тобто частину мідної сировини можна отримати в результаті регенерації з промислових стоків виробництва плат. Як показують численні дослідження, отримана мідь відповідає вимогам і може бути використана в подальшому для переплавки або металізації підкладок при технологічних процесах. В даний час поширені реагентні технології вилучення металів зі стічних вод не забезпечують необхідної ефективності очищення води для іï повторного використання. Це призводить до утворення та накопичення токсичних гальванічних шламів. [2, 3]
Створення нових видів металевих матеріалів з підвищеними механічними, експлуатаційними властивостями неодмінно має супроводжуватися оцінкою їх корозійної стійкості, так як руйнування металу під дією середовища може звести нанівець всі позитивні властивості матеріалу. Це приводить до підвищення попиту на мідно-берилієві сплави. Мобільні телефони, планшети, ноутбуки і інші сучасні мобільні пристрої містять в собі відповідальні деталі, виготовлені з берилієвої бронзи. Найбільш застосовують високолеговані берилієві бронзи з вмістом берилію 2\%, такі як сплав марки БрБ2 або по зарубіжній специфікації 25 (C17200) [3]. Дуже важливо дотримуватися в цих технологіях мінімальне пошкодження поверхневого шару берилієвої бронзи, тому для підготовки поверхні вибирають хімічний процес травлення [4-6].

Актуальним залишається питання токсичності берилієвих технологій і тому, сьогодні ведуться експерименти по створенню мідних сплавів із середньою провідністю без вмісту $B e$. Вони можуть бути виготовлені з широким спектром механічних властивостей, від високо-пластичних до надвисокої міцності, але недоліком $€$ 
висока густина. Очевидно, що зниження густини в мідних сплавах за рахунок варіювання легуючих елементів дуже обмежені і навряд чи будуть вносити значний вклад в істотне збільшення питомої міцності.[7]. Отже берилієва бронза володіє унікальним набором фрізико-механічних властивостей. Крім того, при механічній обробці БрБ2 необхідно добре контролювати виділення токсичного пилу, але і ця проблема успішно вирішується при розмірній обробці мідно-берилієвого сплаву операцією хімічного травлення.

Проблема, їі зв'язок 3 науковими і практичними завданнями.

Аналіз літературних даних показав, що результати вивчення хімічного і анодного розчинення берилієвої бронзи в концентрованих водних середовищах практично відсутні.

При виготовленні друкованих плат застосовують технологічну операцію травлення міді та мідних сплавів. [8]. При травленні мідних сплавів показниками якості $є$ : проведення процесу з високою швидкістю, рівномірністю травлення в часі, рівномірністю по розчиненню компонентів сплаву, великою ємністю розчину по метало-іонам - компонентам сплаву. Крім того, розглядаючи процес травлення з хімічної точки зору, важливо враховувати залежність фактора підтравлювання від природи розчину травлення. Саме тому, основним експериментально-дослідницьким завданням стала розробка хімічних складів травильних розчинів, що поєднують в собі високі показники мікро-травлення і забезпечують створення рівномірного мікрорельєфу з розвиненою площею поверхні [9-11]. Залежно від цього необхідно підбирати склад травильного розчину, який і забезпечує швидкість травлення, «ємність» по іонам компонентів розчинненя металевої фрази, рівномірність розчинення сплаву, термін служби розчину, можливість його регенерації, економічну доцільність використання, якісні показники: відсутність утворення доменів, шламів і підтравлювання.

Мета: Дослідження хімічного розчинення сплаву БрБ2 в розчинах різного складу та оптимізація технологічного процесу травлення берилієвої бронзи за рахунок підбору оптимального складу травильного розчину.

Методи дослідження. Визначення швидкості хімічного травлення за допомогою гравіметричного методу ґрунтувалося на використанні дискового електроду, що обертається (ОДЕ), виготовленого із сплаву БрБ2, при $\omega=74$ об $\cdot \mathrm{c}^{-1}$ (дана швидкість обертання електроду дозволяє імітувати гідродинамічні умови струменевого травлення, тобто виробничі умови технологічного процесу). Елементний склад сплаву БрБ2 визначено гравіметричним методом по ДОСТ 15027.13-77. Масова частка берилію в сплаві БрБ2 становить $1,78 \%$.
Для з'ясування стану матеріалу (сплав БрБ2), а саме загартований або зістарений було проведено визначення твердості сплаву БрБ2 по Бринеллю НВ (рис. 1) на твердомірі UIT-HBW-1S за допомогою програми «Визначення твердості матеріалів втискуванням сферичного індентора»:

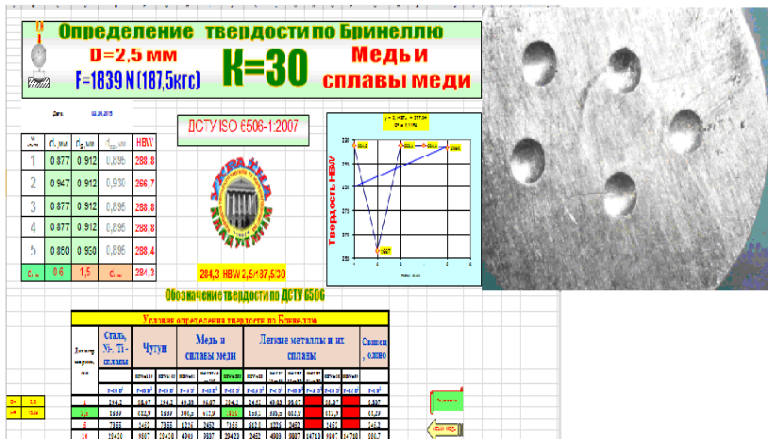

Рис. 1. Визначення твердості сплаву БрБ2 по Бринелю

В основі програми, по якій визначалася твердість лежить ДСТУISO 6506-1. Було визначено, що $H B=284,3$ - що відповідає зістареному стану берилієвої бронзи. [12-13]. Це дуже важливо 3 тієї точки зору того, що процес старіння берилієвої бронзи БрБ2 надає істотний вплив на її фрізико-механічні властивості. Як відомо, особливістю берилієвих бронз $є$ великий діапазон зміни фрізико-хімічних властивостей під час термообробки. В загартованому стані ці сплави володіють високою ударною в'язкістю. Після старіння в'язкість берилієвої бронзи різко знижується, а міцність і твердість зростає. Тому саме властивості, отримані при старінні визначають довгу тривалість та надійність деталей з берилієвої бронзи. [14]. Збільшення мікро-твердості, зміну структури сплаву, розміру і кількості фазових виділень, які з різною ефективністю надають спротив дислокаціям після старіння берилієвої бронзи ретельно досліджено в роботі [15].

Вміст іонів $B e^{2+}$ та $C u^{2+}$ у відпрацьованих травильних розчинах визначали методом атомно-абсорбційної спектрометрії, використовуючи спектрометр атомної абсорбції МРА-915 МД. Результати, отримані за допомогою цього методу дозволяють розрахувати коефіцієнти селективності розчинення компонентів сплаву, які в свою чергу $є$ підставою для висновку про рівномірність або ж селективність розчинення компонентів мідного сплаву. Вибір складу травильних розчинів був обумовлений їх практичним використанням в процесах травлення берилієвої бронзи. Як відомо [16], раніше для травлення берилієвої бронзи використовували кислий розчин на основі $\mathrm{CuCl}_{2}$, основним недоліком якого $є$ низька швидкість травлення і великий боковий підтрав. Крім 
того, утилізація такого розчину приводить до необхідності виділення великої кількості міді, що утруднюється низьким значення ії̈ гранично допустимі концентрації у стічних водах. Слід зауважити і про високу собівартість солей міді. По цим причинам на виробництві використовують більш дешевий травильний розчин, що забезпечує високу швидкість травлення До таких травильних розчинів належить склад на основі $\mathrm{FeCl}_{3}$, який і був обраний за основний склад для приготування модельних розчинів.

Морфологічні особливості протравленої поверхні сплаву БрБ2 вивчали методом електронозондового мікроаналізу (ЕРМА) на скануючому мікроскопі JSM-6390 LV з системою рентгенівського мікроаналізу INCA.

Дослідження швидкості та стабільності процесу хімічного травлення сплаву БРБ2 в часі. Методом обертового дискового електрода (швидкість обертання 74 об/с) було досліджено швидкість розчинення берилієвої бронзи БрБ2 в розчинах різного складу. На підставі отриманих даних була обрана серія з п'яти складів травильних розчинів, які забезпечують високу швидкість травлення берилієвої бронзи (табл.1):

Таблиця 1. Результати дослідження швидкості іонізації сплаву БрБ2 досліджуваних розчинах

(час травлення сплаву БрБ2 20 хв; 25ㅇ)

\begin{tabular}{|c|c|c|}
\hline & Склад розчину , моль/л & 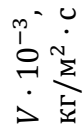 \\
\hline 1 & $0,5 \mathrm{M} \mathrm{FeCl} 3$ & 1,61 \\
\hline 2 & $1,0 \mathrm{M} \mathrm{FeCl} l_{3}$ & 2,99 \\
\hline 3 & $0,5 \mathrm{M} \mathrm{FeCl} l_{3}+0,5 \mathrm{M} \mathrm{Fe}\left(\mathrm{NO}_{3}\right)_{3}$ & 2,2 \\
\hline 4 & $\begin{array}{c}0,5 \mathrm{M} \mathrm{FeCl} l_{3}+0,5 \mathrm{M} \mathrm{Fe}\left(\mathrm{NO}_{3}\right)_{3}+ \\
+0,25 \mathrm{M} \mathrm{H}_{2} \mathrm{SO}_{4}\end{array}$ & 2,3 \\
\hline 5 & $\begin{array}{c}0,5 \mathrm{M} \mathrm{FeCl}_{3}+ \\
+0,5 \mathrm{M} \mathrm{Fe}\left(\mathrm{NO}_{3}\right)_{3}+0,5 \mathrm{M} \mathrm{HCl}\end{array}$ & 2,4 \\
\hline
\end{tabular}

3 метою визначення відсутності пасивації поверхні електроду з берилієвої бронзи було проведено аналіз протравленої поверхні сплаву БрБ2 на скануючому мікроскопі JSM-6390 LV з системою рентгенівського мікроаналізу INCA. Результати електроно-зондового мікроаналізу (ЕРMA) показали, що не спостерігається утворення щільних пасивуючих плівок на поверхні протравленого бронзового електроду в досліджуваних травильних розчинах, що можна бачити на мікрофотографріях поверхні з БрБ2 (рис 2). На зразках електродів зі сплаву БрБ2 після травлення помітні білі мілкі кристали. Можна передбачити сольову та оксидну природу цих кристалів. Це підтверджено результатами електроно-зондового мікроаналізу, оскільки фокусування електронного пучка на кристали показало наявність хлоридів.

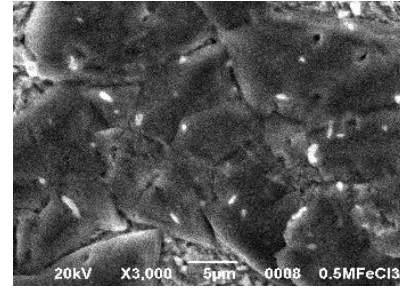

a

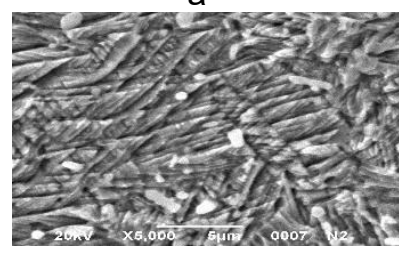

B

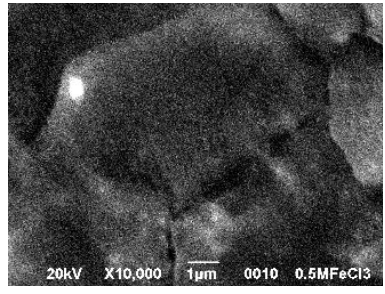

6

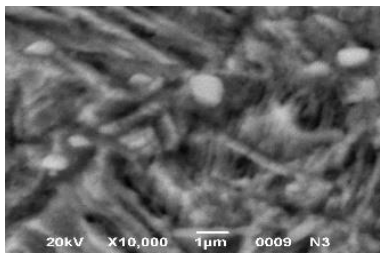

Рис. 2. Мікрофротографії поверхні бронзи БрБ2 після травлення $\left(\omega=74\right.$ об $\left.\cdot \mathrm{c}^{-1}\right)$ в розчинах: а,б - 0,5M FeCl 3 збільшення: a - 3000 разів; б- 10000 разів;

в $-0,5 \mathrm{M} \mathrm{FeCl} 3+0,5 \mathrm{M} \mathrm{Fe}\left(\mathrm{NO}_{3}\right)_{3}+0,25 \mathrm{M} \mathrm{H}_{2} \mathrm{SO}_{4}$ збільшення - 5000 разів;

$\Gamma-0,5 \mathrm{M} \mathrm{FeCl} l_{3}++0,5 \mathrm{M} \mathrm{Fe}\left(\mathrm{NO}_{3}\right)_{3}+0,5 \mathrm{M} \mathrm{HCl}$ збільшення - 10000 разів

На підставі результатів дослідження електроно-зондового аналізу зрозуміло, що обрані склади травильних розчинів забезпечують високу швидкість травлення, а також не викликають пасивації поверхні.

Однак дані результати стосуються швидкості травлення латуні тільки в початковий момент часу. По мірі розчинення компонентів сплаву БрБ2 змінюється склад травильного розчину i, відповідно, швидкість розчинення компонентів сплаву. У зв'язку з цим дуже важливою $є$ перевірка стабільності процесу травлення берилієвої бронзи в часі. Для цього були зняті $V-\tau-$ криві зміни швидкості розчинення сплаву БрБ2, представлені на рис. 3:

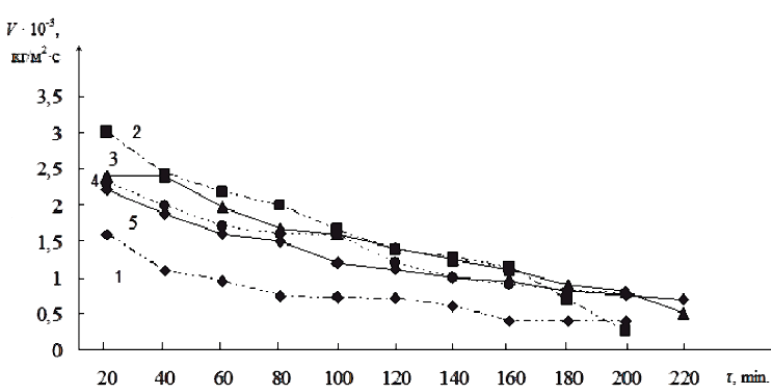

Рис. 3. Зміна швидкості травлення сплаву БрБ2 в часі. У розчинах складу моль/л:

1 - 0,5 $\mathrm{M} \mathrm{FeCl}_{3} ; 2$ - 1,0 $\mathrm{M} \mathrm{FeCl} 3$; 3 - 0,5 $\mathrm{M} \mathrm{FeCl}_{3}+$ $0,5 \mathrm{M} \mathrm{Fe}\left(\mathrm{NO}_{3}\right)_{2}+0,5 \mathrm{M} \mathrm{HCl} ; 4-0,5 \mathrm{M} \mathrm{FeCl} 3+$ $0,5 \mathrm{M} \mathrm{Fe}\left(\mathrm{NO}_{3}\right)_{2}+0,25 \mathrm{M} \mathrm{H}_{2} \mathrm{SO}_{4} ; 5-0,5 \mathrm{M} \mathrm{FeCl} \mathrm{Cl}_{3}+$ $0,5 \mathrm{M} \mathrm{Fe}\left(\mathrm{NO}_{3}\right)_{2}$ 
Вид кривих $V-\tau-$ (рис. 3) подібний до кривих при травленні чистої міді та мідних сплавів[16]. Ми розглядали нахил прямолінійної ділянки кривої $v-T$ в середині циклу травлення. Для травильних розчинів, що мають східчастий вид залежності $v$ - $т$ виділення однієї прямолінійної ділянки неможливо. Це не означає, що чим менше швидкість травлення, тим процес більш тривалий и навпаки. В деяких розчинах відбувається різке припинення травлення з випадінням осаду малорозчинної сполуки, при цьому нахил кривої $V-\tau-$ малий. Дуже важливо підібрати такий склад розчинів для травлення, щоб швидкість розчинення сплаву протягом початкового періоду підвищувалася або зменшувалася не різко, а в середині циклу травлення була б стабільна на проміжному рівні - криві 1, 3 и 4 рис. 3. Згідно з експериментальними даними рис. 3 були обчислені показники травлення, а саме максимальна, мінімальна і середня в часі швидкість травлення сплаву, різниці між значеннями швидкості травлення берилієвої бронзи за цикл травлення, які і наведені в таблиці 2.

Кількісні характеристики травлення для складів розчинів, рекомендованих як високошвидкісні (криві 3 і 4, рис. 3), одночасно відрізняються найбільш високими значеннями різниці швидкостей травлення бронзи БрБ2 $\left(V_{\text {max }}-V_{\text {min }}\right), \quad\left(V_{\text {max }}-V_{\text {med }}\right)$ і $\left(V_{\text {med }}-V_{\text {min }}\right)$ (склади розчинів 3 і 4 відповідно в таблиці 2). Саме дані показники, а не первісне значення швидкості травлення, оптимально характеризують здатність розчину до тривалого високошвидкісного травлення сплаву.

Таблиця 2. Кількісні характеристики травлення сплаву БрБ2

\begin{tabular}{|c|c|c|c|c|c|c|c|}
\hline \multirow{2}{*}{$\begin{array}{l}\text { 듣 } \\
\text { 인 }\end{array}$} & \multirow{2}{*}{ Склад розчину, моль/л } & \multicolumn{3}{|c|}{ 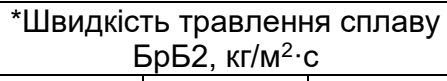 } & \multicolumn{3}{|c|}{$\begin{array}{c}\text { Різниця між значеннями швидкості } \\
\text { травлення сплаву БрБ2 }\end{array}$} \\
\hline & & $V_{\max }$ & $V_{\min }$ & $V_{\text {med }}$ & $V_{\max }-V_{\min }$ & $V_{\max }-V_{\text {med }}$ & $V_{m e d}-V_{\min }$ \\
\hline 1 & $0,5 \mathrm{M} \mathrm{FeCl} l_{3}$ & 1,61 & 0,39 & 1 & 1,22 & 0,61 & 0,61 \\
\hline 2 & $0,5 \mathrm{M} \mathrm{FeCl} 3+0,5 \mathrm{M} \mathrm{Fe}\left(\mathrm{NO}_{3}\right)_{2}$ & 2,0 & 0,7 & 1,35 & 1,3 & 0,65 & 0,65 \\
\hline 3 & $\begin{array}{l}0,5 \mathrm{M} \mathrm{FeCl} 3+0,5 \mathrm{M} \mathrm{Fe}\left(\mathrm{NO}_{3}\right)_{2}+ \\
+0,25 \mathrm{M} \mathrm{H}_{2} \mathrm{SO}_{4}\end{array}$ & 2,2 & 0,77 & 1,5 & 1,43 & 0,7 & 0,73 \\
\hline 4 & $\begin{array}{l}0,5 \mathrm{M} \mathrm{FeCl} 3+0,5 \mathrm{M} \mathrm{Fe}\left(\mathrm{NO}_{3}\right)_{2}+ \\
+0,5 \mathrm{M} \mathrm{HCl}\end{array}$ & 2,5 & 0,8 & 1,65 & 1,7 & 0,85 & 0,85 \\
\hline 5 & $1,0 \mathrm{M} \mathrm{FeCl} 3$ & 2,7 & 0,3 & 1,5 & 2,4 & 1,2 & 1,2 \\
\hline
\end{tabular}

${ }^{*} V_{\text {max }}$ - максимальне значення швидкості травлення сплаву БрБ2 за цикл травлення; $V_{\min }-$ мінімальне значення швидкості травлення сплаву БрБ2 за цикл травлення; $V_{\text {med }}-$ середнє значення швидкості травлення сплаву БрБ2 за цикл травлення.

Висока швидкість травлення в розчині $1,0 \mathrm{M} \mathrm{FeCl}$ (крива 2, рис.3) в порівнянні іншими обумовлена, перш за все, найбільшою концентрацією іона - окислювача $\mathrm{Fe}^{3+}$.

Швидкість розчинення сплаву зростає як в залежності від концентрації іона $F e^{3+}$, так і від сумарної концентрації іонів хлору і $\mathrm{pH}$ розчину, що забезпечують добавки до розчину $0,5 \mathrm{M} \mathrm{FeCl}$ у вигляді $\mathrm{Fe}\left(\mathrm{NO}_{3}\right)_{2}$ та кислот $\mathrm{HCl}, \mathrm{H}_{2} \mathrm{SO}_{4}$. Саме цим можна обґрунтувати високошвидкісне травлення сплаву БрБ2 в розчині

$0,5 \mathrm{M} \mathrm{FeCl} \mathrm{Cl}_{3}+0,5 \mathrm{M} \mathrm{Fe}\left(\mathrm{NO}_{3}\right)_{2}+0,5 \mathrm{M} \mathrm{HCl}$.

Крім того, зростання швидкості розчинення берилієвої бронзи можна пояснити утворенням в розчині комплексів заліза (III), що активують розчинення мідної складової сплаву, в той час як зниження $\mathrm{pH}$ розчину забезпечує розчинення берилієвої компоненти сплаву БрБ2.

Високошвидкісне та стабільне протягом усього циклу травлення забезпечують склади розчинів:

- 0,5 $\mathrm{M} \mathrm{FeCl}_{3}$

$-0,5 \mathrm{M} \mathrm{FeCl} l_{3}+0,5 \mathrm{M} \mathrm{Fe}\left(\mathrm{NO}_{3}\right)_{2}+0,5 \mathrm{M} \mathrm{HCl}$

$-0,5 \mathrm{M} \mathrm{FeCl}+0,5 \mathrm{M} \mathrm{Fe}\left(\mathrm{NO}_{3}\right)_{2}+0,25 \mathrm{M} \mathrm{H}_{2} \mathrm{SO}_{4}$
Дослідження рівномірності розчинення берилієвої бронзи. Розчинення берилієвої бронзи проводили в одному і тому ж об'ємі розчину до появи завислої твердої фази. Концентрації металоіонів в відпрацьованих розчинах, визначені атомно-абсорбційним методом, представлені в таблиці 3. Удосконалити технологічний процес травлення можна за рахунок збільшення його тривалості без скидання відпрацьованих розчинів в промисловий стік. У цьому випадку використовують розчини, що мають найбільш високу ємність по компонентам сплаву - це розчини складу 3 (22,1 г/л) і складу 4 (22,2г/л) таблиці 3. Сумарна концентрація іонів міді і берилію в даний момент часу відповідала «ємності» розчину по компонентам сплаву БрБ2, які розчиняються.

Дуже важливо для оптимізації технологічного процесу травлення, щоб склад травильного розчину забезпечував рівномірність розчинення компонентів берилієвої бронзи. Кількісними показниками, за допомогою яких можна судити про рівномірність або вибірковість розчинення сплавів, $\epsilon$ коефіцієнти селективності розчинення компонентів сплаву $Z$. 
Тому розчини, що відрізняються високою швидкістю травлення було досліджено на рівномірність розчинення компонентів сплаву, що оцінювали по значенням коефіцієнтів селективності $(Z)$ міді та берилію. Наприклад $Z_{B e}$ розраховували по формулі:

$$
Z_{B e}=\frac{(B e / C u)_{\text {розчин }}}{(B e / C u)_{\text {сплав }}}
$$

де $(\mathrm{Be} / \mathrm{Cu})_{\text {розчин }}$ - відношення концентрацій у розчині, що визначалося методом атомно-абсорбційної спектрометрії; $(B e / C u)_{\text {сплав }}$ - відношення компонентів у сплаві.

Як видно з рис.4 коефіцієнти селективності після 200 хв. травлення найбільш близькі в розчині - 0,5M Fe $\mathrm{Cl}_{3}$. Починаючи з розчину складу 2 і далі 3, 4, 5 (рис.4) можна говорити про збільшення вибіркового розчинення мідної компоненти сплаву. Це можна пояснити східчастою іонізацією мідної складової сплаву БрБ2, тобто спочатку до $C u(I)$, потім по другій сходинці відбувається окислення сполук $C u(I)$ розчиненим киснем. Щодо іонів берилію, то вони з іонами хлору утворюють малостійкі комплекси. Отже, з усіх досліджуваних розчинів саме склад розчину

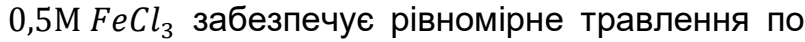
обом компонентам сплаву після тривалого травлення (розчин 1 рис 4).Селективність розчинення міді більш виражена в розчинах складу $3,4,5$ для яких значення $\mathrm{pH}$ нижче. Однією з причин цього може бути підвищення стійкості мідно-хлоридних комплексів [17].

Таблиця 3. Результати атомно - абсорбційного аналізу виснажених травильних розчинів (час травлення сплаву БрБ2 200 хв.; 25)

\begin{tabular}{|c|c|c|c|c|c|}
\hline \multirow[b]{2}{*}{$\begin{array}{l}\text { 드 } \\
\text { 디 } \\
\text { 인 }\end{array}$} & \multirow[b]{2}{*}{$\begin{array}{c}\text { Склад розчину, } \\
\text { моль/л }\end{array}$} & \multirow{2}{*}{ 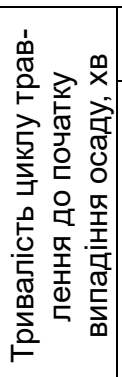 } & \multicolumn{2}{|c|}{$\begin{array}{l}\text { Концентрації } \\
\text { іонів, г/л }\end{array}$} & \multirow{2}{*}{ 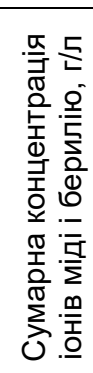 } \\
\hline & & & $B e^{2+}$ & $C u^{2+}$ & \\
\hline 1 & $0,5 \mathrm{M} \mathrm{FeCl}{ }_{3}$ & 160 & 0,175 & 10,27 & 10,45 \\
\hline 2 & $\begin{array}{l}0,5 \mathrm{M} \mathrm{FeCl}{ }_{3}+ \\
+0,5 \mathrm{M} \mathrm{Fe}\left(\mathrm{NO}_{3}\right)_{2}\end{array}$ & 180 & 0,291 & 19,98 & 20,27 \\
\hline 3 & $\begin{array}{l}0,5 \mathrm{M} \mathrm{FeCl}+ \\
+0,5 \mathrm{M} \mathrm{Fe}\left(\mathrm{NO}_{3}\right)_{2}+ \\
+0,25 \mathrm{M} \mathrm{H}_{2} \mathrm{SO}_{4}\end{array}$ & 160 & 0,304 & 21,78 & 22,1 \\
\hline 4 & $\begin{array}{l}0,5 \mathrm{M} \mathrm{FeCl} l_{3}+ \\
+0,5 \mathrm{M} \mathrm{Fe}\left(\mathrm{NO}_{3}\right)_{2}+ \\
+0,5 \mathrm{M} \mathrm{HCl}\end{array}$ & 180 & 0,281 & 21,93 & 22,2 \\
\hline 5 & $1,0 \mathrm{M} \mathrm{FeCl} 3$ & 160 & 0,222 & 20,8 & 21,0 \\
\hline
\end{tabular}

Коефіцієнти $Z_{B e}$ і $Z_{C и}$ для берилієвої бронзи були розраховані на підставі результатів атомноабсорбційного аналізу розчинів за концентраціями іонів міді і берилію, які перейшли в розчин, і за даними про точний склад сплаву БрБ2 (рис. 2):

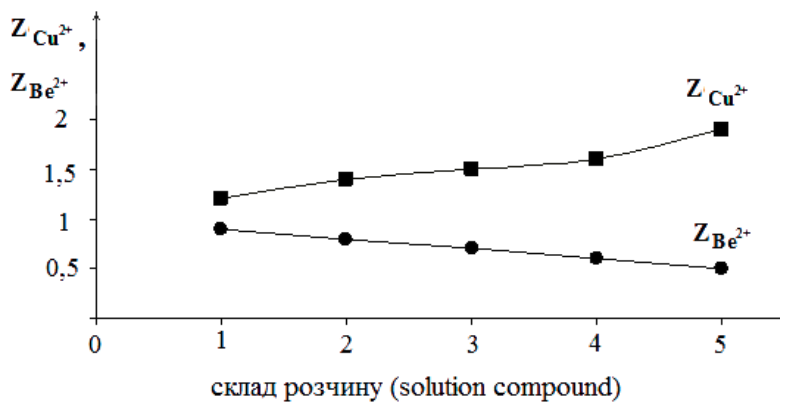

Рис. 4. Коефіцієнти селективності розчинення компонентів сплаву БрБ2 після 200 хв травлення в розчинах різного складу:

$1-0,5 \mathrm{M} \mathrm{FeCl} l_{3} ; 2-0,5 \mathrm{M} \mathrm{FeCl} l_{3}+0,5 \mathrm{M} \mathrm{Fe}\left(\mathrm{NO}_{3}\right)_{2}$;

$3-0,5 \mathrm{M} \mathrm{FeCl} l_{3}+0,5 \mathrm{M} \mathrm{Fe}\left(\mathrm{NO}_{3}\right)_{2}+0,25 \mathrm{M} \mathrm{H}_{2} \mathrm{SO}_{4}$;

$4-0,5 \mathrm{M} \mathrm{FeCl} 3+0,5 \mathrm{M} \mathrm{Fe}\left(\mathrm{NO}_{3}\right)_{2}+0,5 \mathrm{M} \mathrm{HCl}$

$$
5-1,0 \mathrm{M} \mathrm{FeCl}
$$

\section{Висновки:}

1. Досліджено процес хімічного розчинення берилієвої бронзи в розчинах різних електролітів та стабільність його в часі. Запропоновано склади розчинів високошвидкісного травлення сплаву БрБ2 при довготривалому процесу:

$$
\begin{aligned}
& -0,5 \mathrm{M} \mathrm{FeCl} \\
& -0,5 \mathrm{M} \mathrm{FeCl} 3+0,5 \mathrm{M} \mathrm{Fe}\left(\mathrm{NO}_{3}\right)_{2}+0,5 \mathrm{M} \mathrm{HCl} \\
& -0,5 \mathrm{M} \mathrm{FeCl} l_{3}+0,5 \mathrm{M} \mathrm{Fe}\left(\mathrm{NO}_{3}\right)_{2}+0,25 \mathrm{M} \mathrm{H}_{2} \mathrm{SO}_{4}
\end{aligned}
$$

2. Вивчено селективність розчинення компонентів сплаву БрБ2 при довготривалому травленні та визначено, що склад розчину $0,5 \mathrm{M} \mathrm{FeCl} 3$ забезпечує рівномірне травлення по обом компонентам сплаву БрБ2 ;

3. Вивчено морфологію поверхні електрода з БрБ2 після травлення в розчинах, склад яких забезпечує найбільші показники швидкості і близькі до 1 значення коефіцієнтів селективності розчинення компонентів сплаву. Показано відсутність пасивування поверхні після хімічного травлення в цих розчинах. Встановлено хімічну природу сполук, що утворюються у вигляді дрібних включень на протравленій поверхні електроду;

4. Отримані результати мають велике значення в практичному використанні, оскільки дозволяють підібрати склад травильного розчину, що в свою чергу сприяє оптимізації технологічного процесу травлення і поповнюють базу наукових даних про хімічний розчиненні мідних сплавів. 


\section{Література:}

1. Нестер А. Эколого-экономические аспекты регенерации отработанных растворов травления гальванических производств / А.Нестер // TRANSPORT. TRANSPORT FACILITIES. ECOLOGY. - 2018 - №3 - C.52 - 58

2. Алдунин А.В. Исследование, разработка и внедрение эфффективных технологий производства полос и лент из стали и сплавов цветных металлов с заданными структурой и свойствами: дис. д-ра техн. наук: - М., 2011. - 369 с.

3. Нестер А.А. Очистка сточных вод производства печатных плат: монография. - Хмельницкий: Изд-во Хмельницкого нац. Ун-та, 2016. - 219 с.

4. Тебякин А. Многофункциональные медные сплавы / А. Тебякин, А.Фоканов, В. Подуражная // Труды ВИАМ. - 2016 - № 12(48) - С. 37-44.

5. Качагин А. Создание комплекса изготовления пружинных деталей / А. Качагин, Н. Кривохижина, А. Савицкий, Н. Короткова // Производство электроники: технологии, оборудование, материалы. - 2008 - № 5 - С. 41-46.

6. Медведев А. Материалы для гибких печатных плат / А. Медведев // Технологии в электронной промышленности. - 2011 - № 3- C.12-19.

7. Walker P. Handbook of metal etchants / P. Walker, W. H. Tarn / CRC Press LLC Boca Raton Boston London NewYork Washington, D.C., 1991 - 1415 p.

8. Altenberger I. Material properties of high-strength beryllium-free copper alloys / I. Altenberger, $\mathrm{H}$. A. Kuhn and H. R. Müller // Int. J. Materials and Product Technology. - 2015-Vol. 50, No. 2, - P.124-145.

9. Медведев А. Конструкции и принципы изготовления печатних плат / А. Медведев // Технологии в электронной промышленности. - 2011 № 4 - С. $12-18$.

10. Смертина Т. Подготовка поверхности меди. Механическая или химическая? / Т. Смертина // Технологии в элекронной промышленности. 2011 - № 3 - с. 12-19.

11. Смертина Т. Высокоточное травление. От теории к практике / Т.Смертина // Технологии в электронной промышленности. 2008 - № 3 - с. 12-19.

12. Свідоцтво про реєстрацію авторського права на твір 48174 Україна. Визначення твердості матеріалів втискуванням сферичного індентора / Мощенок В.І. - авторські права належать Мощенок В.І., ХНАДУ, дата реєстрації 04.03.2013.

13. Осинцев О.Е. Медь и медные сплавы Отечественные и зарубежные марки.: Справочник / О.Е. Осинцев., В.Н. Федоров - М: Машиностроение, 2004. - 336 с.

14. Способы металлографического травления: Справ. изд.: Пер. с нем. Беккерт М., Клемм Х. 2-е изд., перераб. и доп. М.: Металлургия, 1988. С. 400 с ил.

15. Ю.В. Осинская, С.С. Петров, А.В. Покоев Комплексное экспериментальное исследование магнитнопластического эфффекта в медно-бериллиевом сплаве // Вестник СамГУ-Естественнонаучная серия. 2010 № 4 (78) с.145-154

16. Качагин А. Создание комплекса изготовления пружинных деталей / А. Качагин, Н. Кривохижина, А. Савицкий, Н. Корткова // Производство электроники: технологии, оборудование, материалы.- 2008 - № 5 - С. 41-46.

17. Ларин В.И, Егорова Л. Химическая ионизация сплава бериллиевой бронзы в хлоридных растворах / Укр. хим. журнал. - 2018. - Т. 84, №3. - C. 20-27.

\section{References:}

1. Nester, A., 2018. Ekologo-ekonomicheskie aspektyi regeneratsii otrabotannyih rastvorov travleniya galvanicheskih proizvodstv. TRANSPORT. TRANSPORT FACILITIES. ECOLOGY, (№ 3), pp.52-58.

2. Aldunin, A., 2011. Issledovanie, Razrabotka I Vnedrenie Effektivnyih Tehnologiy Proizvodstva Polos I Lent Iz Stali I Splavov Tsvetnyih Metallov S Zadannyimi Strukturoy I Svoystvami. d-ra tehn. nauk. Moscow State University.

3. Nester, A., 2016. Ochistka Stochnyih Vod Proizvodstva Pechatnyih Plat. Hmelnitskiy: Izd-vo Hmelnitskogo nats. Un-ta, p.219.

4. Tebyakin, A., Fokanov, A. and Podurazhnaya, V., 2016. Mnogofunktsionalnyie mednyie splavyi. Trudyi VIAM, (№ 12(48), pp.37-44.

5. Kachagin, A., Krivohizhina, N., Savitskiy, A. and Korotkova, N., 2008. Sozdanie kompleksa izgotovleniya pruzhinnyih detaley. Proizvodstvo elektroniki: tehnologii, oborudovanie, materialyi., (№ 5), pp.41-46.

6. Medvedev, A., 2011. Materialyi dlya gibkih pechatnyih plat. Tehnologii $v$ elektronnoy promyishlennosti., (№ 3), pp.12-19.

7. Walker, P. and Tarn, W., 1991. Handbook Of Metal Etchants. Washington: CRC Press LLC Boca Raton Boston London NewYork Washington, D.C., p.1415 p.

8. Altenberger, I., Kuhn, H. and Müller, H., 2015. Material properties of high-strength beryllium-free copper alloys. Int. J. Materials and Product Technology, Vol. 50(No. 2), pp.124-145.

9. Medvedev, A., 2011. Konstruktsii i printsipyi izgotovleniya pechatnih plat. Tehnologii $v$ elektronnoy promyishlennosti, (No. 4), pp.12-18.

10. Smertina, T., 2011. Podgotovka poverhnosti medi. Mehanicheskaya ili himicheskaya?. Tehnologii v elekronnoy promyishlennosti, (No. 3), pp.12-19.

11. Smertina, T., 2008. Vyisokotochnoe travlenie. Ot teorii k praktike. Tehnologii $v$ elektronnoy promyishlennosti, (№ 3), pp.12-19.

12. Moschenok, V., 2013. Viznachennya Tverdosti Materialiv Vtiskuvannyam Sferichnogo Indentora. Svldotstvo pro reEstratslyu avtorskogo prava na tvIr 48174. 
13. Osintsev, O. and Fedorov, V., 2004. Med IMednyie Splavyi Otechestvennyie I Zarubezhnyie Marki. .: Spravochnik. Moskva: Mashinostroenie, p.336.

14. Bekkert, M. and Klemm, X., 1988. Sposobyi Metallograficheskogo Travleniya: Sprav. Izd.:. 2nd ed. Moskva: Metallurgiya, p.400.

15. Osinskaya, Y., Petrov, S. and Pokoev, A., 2010. Kompleksnoe eksperimentalnoe issledovanie magnitnoplasticheskogo effekta $v$ medno-berillievom splave. Vestnik SamGU-Estestvennonauchnaya seriya, (№ 4 (78)), pp.145-154.

16. Kachagin, A., Krivohizhina, N., Savitskiy, A. and Kortkova, N., 2008. Sozdanie kompleksa izgotovleniya pruzhinnyih detaley. Proizvodstvo elektroniki: tehnologii, oborudovanie, materialyi., (№ 5), pp.41-46.

17. Larin, V. and Egorova, L., 2018. Himicheskaya ionizatsiya splava berillievoy bronzyi $\mathrm{v}$ hloridnyih rastvorah. Ukr. him. zhurnal., T. 84(№3), pp.20-27.

\title{
Аннотация
}

\section{Химическое травление сплава БрБ2 в разных электролитах}

\author{
Л.М. Егорова, В.В. Даценко, В.В. Ларин
}

Исследован процесс химической ионизации сплава БрБ2 в растворах различного состава на основе $\mathrm{FeCl}_{3}$. На основании первоначальных исследований определения скорости ионизации сплава $\mathrm{Cu} 98 \mathrm{Be}$ в различных электролитах раствор $\mathrm{FeCl}_{3}$ был выбран основным компонентом раствора для травления. Выбрана серия из пяти составов растворов для травления, которые обеспечивают высокую скорость травления и равномерное растворение компонентов бериллиевой бронзы. По мере растворения компонентов сплава БрБ2 меняется состав травильного раствора и, соответственно, скорость растворения компонентов сплава. В связи с этим очень важна проверка стабильности процесса травления бериллиевой бронзы во времени. Для этого было исследовано изменение скорости растворения сплава БрБ2 во времени. Согласно экспериментальным данным были вычислены количественные показатели травления и предложен состав растворов, обеспечивающие высокую скорость. С целью определения селективности химического растворения БрБ2 был изучен процесс травления в растворах хлорида железа в течение длительного периода времени. В качестве количественных показателей равномерности травления были определены коэффициенты селективности растворения компонентов сплава. Показано, что равномерное и высокоэффективное химическое растворение бериллиевой бронзы возможно в кислых средах в присутствии иона-окислителя $F e^{3+}$ и ионов хлора. Предложены оптимальные составы травильных растворов, обеспечивающие качественное травление бериллиевой бронзы по нескольким критериям - высокая скорость процесса, равномерное растворение компонентов сплава, высокая емкость обоих компонентов бериллиевой бронзы. Полученные результаты имеют большое значение при практическом использовании, поскольку позволяют выбрать состав травильного раствора, что, в свою очередь, помогает оптимизировать технологический процесс травления.

Ключевые слова: бериллиевая бронза, травление, травильные растворы, селективность растворения.

\section{Abstract}

\section{Chemical etching of Cu98Be alloy in various electrolytes}

\section{L.M. Egorova, V.V. Datcenko, V.I. Larin}

The process of chemical ionization of Cu98Be alloy in solutions of various composition based on $\mathrm{FeCl}_{3}$ was investigated. On the base of first investigations of determination of the ionization rate of Cu98Be alloy in various electrolytes, the solution of $\mathrm{FeCl}_{3}$ was chosen as a basic component of etching solution.. The series of five composition of etching solutions which provide high etching rate and uniform dissolution of beryllium bronze components was selected. As the components of Cu98Be alloy dissolutions the composition of the etching solution and the rate of dissolution of the alloy components were changes. Therefore, it is very important to check the stability of the etching process of beryllium bronze. In this regard, the change in the rate of dissolution of the alloy Cu98Be over time was investigated. According to the experimental data the quantitative indices of etching were calculated and the composition of the solutions, which provide a high speed was proposed With the aim of determination was investigated of beryllium bronze chemical dissolution selectivity the etching process in ferric chloride solutions during the long period of time was studied. As the quantitative indexes of Cu98Be alloy etching evenness the coefficients of alloy components dissolution selectivity were 
determined. It was shown that equable and high rated chemical dissolution of beryllium bronze is possible in acidic media in presence of $\mathrm{Fe}^{3+}$ ion-oxidizer and chlorine ions. The optimal compositions of etching solutions, whit provide high-quality etching of beryllium bronze according to several criteria - high process speed, uniform dissolution of alloy components, high capacity for both components of beryllium bronze was proposed. The obtained results are of great importance in practical use because they allow selecting the composition of the etching solution, which in turn helps to optimize the technological etching process.

Keywords: beryllium bronze; etching; etching solution; dissolution selectivity.

\section{Бібліографічне посилання/ Bibliography citation: Harvard}

Egorova, L. M., Datcenko, V. V. and Larin, V. I. (2020) 'Chemical etching of Cu98Be alloy in various electrolytes', Engineering of nature management, (4(18), pp. 60 - 67.

Подано до редакції / Received: 15.10.2020 